\title{
The Role of China and India in Brazil's Economy
}

\author{
Raul Gouvea ${ }^{1 *}$, Shihong Li² $^{2}$, Gautam Vora ${ }^{3}$ \\ ${ }^{1}$ Visiting Research Fellow at UERJ, Albuquerque, NM, USA \\ ${ }^{2}$ Accounting, Anderson School of Management, University of New Mexico, Albuquerque, NM, USA \\ ${ }^{3}$ Finance, Anderson School of Management, University of New Mexico, Albuquerque, NM, USA \\ Email: *rauldg@unm.edu, shli@unm.edu,vora@unm.edu
}

How to cite this paper: Gouvea, R., Li, S. H., \& Vora, G. (2021). The Role of China and India in Brazil's Economy. Modern Economy, 12, 1263-1285.

https://doi.org/10.4236/me.2021.128066

Received: August 20, 2019

Accepted: August 27, 2021

Published: August 30, 2021

Copyright $\odot 2021$ by author(s) and Scientific Research Publishing Inc. This work is licensed under the Creative Commons Attribution International License (CC BY 4.0).

http://creativecommons.org/licenses/by/4.0/

\begin{abstract}
This paper elaborates on the expanding role of both China and India in Latin America. More specifically, we focus on the growing relationship between Brazil with China and India to illustrate the growing economic impact of China and India on Brazil's economy and business environment. China's "Belt and Road Initiative" has integrated Brazil's economy into the Chinese economy. India is following on China's footsteps expanding its role in Brazil's economy as well. There is a great potential for synergies between Brazil and China and India. This increasing economic integration, however, brings a number of challenges and opportunities for all three countries involved.
\end{abstract}

\section{Keywords}

International Trade, Exports and Imports, BRIC Countries, Comparative Analysis, Brazil, China, India

\section{Introduction}

Brazil stands as a unique experiment in Latin America. Portugal ruled Brazil since 1500 until independence in 1822 when Brazilian Empire was declared and formed in 1825 when Portugal signed the Treaty of Rio de Janeiro with independent Brazil. The colonial period was characterized by changes in demographics and economy. The native Brazilian population consisted of mainly hunter-gatherers, with a small number moving towards primitive agriculture. The colony allowed the Portuguese to develop commodity exports and earn commercial profits. The economy went through the phases of exporting sugar, gold, and then diamonds, ending in agricultural products. At the time of independence, the main exports were cotton, sugar and coffee. At the end of the colonial period, half the population was slaves, consisting of blacks, mulattos, in- 
digenous individuals. A privileged fraction of white, dominantly the Portuguese, enjoyed high income, but the rest of the population suffered extreme disparity of income/wealth, education, health, economic opportunity, etc. The regional disparity was noticeable. After the British blockade of slave trade, starting in 1833, Brazil provided incentives to immigrants from Italy, Japan, Germany and Lebanon. Politically and socially Brazil has been lucky compared with other countries in Latin America. Brazil has seen softer political transitions of power, few foreign conflicts and relative ease of social relations between ethnic groups. The current boundaries of the country show the effects of favorable fortuitous events: The Treaty of Tordesilhas signed in 1494 divided the Americas amicably between Portugal and Spain. Portugal was awarded a slice extending 48 degrees west of the Greenwich meridian; the current borders, however, cover nearly three times as much land. Most of the territorial gain was accomplished by frontiersmen. This was endorsed by the Treaty of Madrid in 1750. Brazil has fought relatively few wars to preserve its territorial integrity. This brief history brings into sharp relief the mindset of the population and ruling class of the country. Many of the traits developed during five centuries of existence continue to inform the economics and politics of the country (Amorim, 2006; Baer, 2013; Furtado, 2005; Gouvea, 2020; Simonsen, 1974).

Brazil is the largest country in Latin America, both in population and in land-mass. While it does not speak Spanish, it does speak a closely-related Romance language. Its influence is noticeable in the continent and often world-wide. Yet one can say that Brazil has not taken its rightful place in the hierarchy of countries. Among many factors holding the country back is its economic development. International trade is an important component of economic development. The aforementioned brief history of Brazil suggests that it has traditionally lacked manufacturing prowess and instead depended on extractive industries and agriculture for uplifting its populace. Because of the economic rise of China and its inroads in Brazilian economy, it is important to ask whether this relationship has been beneficial to Brazil. Once India liberalized its economic policies, the informal contacts with Brazil have turned into formal, official economic relationship with Brazil. Therefore, it is important to ask whether this relationship has been beneficial to Brazil. This study is an attempt to lay out the conceptual framework for studying the relationships between Brazil on one hand and China and India on the other. Note that the study is more qualitative than one would expect. It is necessarily so because of limitations of space. An analysis of trade and foreign direct investment (FDI) requires a lot of data and econometric work which would form another set of independent studies. As can be gleaned, the focus is on Brazil, not on China or India; the focus is on trade and not on political influence per se. This makes the current study unique in its objective (Ianni, 1992; Kume, Piani, \& Miranda, 2005; Gouvea \& Kassicieh, 2009).

Brazil has had a significant economic relationship with Asian countries, notably Japan. For instance, from the 1970s to the 1990s, Japan was Brazil's main Asian trading and investment partner. However, in the early 2000s, after years of 
economic stagnation, Japan was replaced by China as Brazil's main Asian trading and investment partner. Recently, India has followed in China's footsteps, increasing its economic and political relations with Brazil as well as with a number of other Latin American countries.

In the 2000s, Brazil emerged as a strategic partner for both China and India in their mutual quest to secure natural resources and markets for emerging manufacturing products and services. For Brazil, China became a strategic trade and investment partner, and a major destination for a number of its agri-business products and mining products. China offered Brazil a new economic momentum for its economy in the first two decades of the 2000s, increasingly integrating Brazil into its expanding "Belt and Road Initiative" (De La Torre et al., 2015; Guilhon-Albuquerque, 2017; Herrero \& Xu 2019).

China and India simultaneously expanded their economies extremely fast in the last two decades. In 2018, China was the second largest economy in the world, accounting for close to $15 \%$ of the global Gross Domestic Product (GDP), and accounting for $25 \%$ of global manufacturing output. China transitioned from a self-imposed economic isolation to a central player in the global economy. Today, China is an integral part of international trade, investment, and financing for the global economy. India is also one of the leading global economic players, accounting for close to $7 \%$ of the global GDP, and is a major player in the global IT industry (Peters, 2015; Dieppe, 2018).

China has the second largest economy in the world, is the world's largest exporter, second largest importer, and has the largest manufacturing park in the world. China's currency, the Renminbi (Yuan) is gradually becoming a global currency. China is also a leader in the creation of new multilateral economic and financial institutions like the "Asian Infrastructure Investment Bank," as well as the "New Development Bank". Moreover, China has been instrumental in establishing the Asian Infrastructure Investment Bank and the Silk Road Investment Fund. Contrary to both Brazil and India, China can be considered an engine of economic growth not only for Asia, but also for the global economy (Danns \& Danns, 2017; Economy, 2018).

Brazil, China, and India also play a foundational role in creating new multilateral agencies and new approaches to govern global trade. For instance, Brazil, China and India were instrumental in the creation of the G-20 during the World Trade Organization (WTO) Cancún round of trade negotiations. G-20 member countries account for $60 \%$ of the world's population, $70 \%$ of the world's farming population, and $25 \%$ of the world's farming exports. The group wants to further liberalize trade in agricultural products by eliminating subsidies and non-tariff barriers for agricultural products by developed countries (Dollar, 2017; Harris \& Arias, 2016; Niu, 2016).

These economic and political relationships have deepened and intensified, creating vital and strategic relationships for Brazil. Both bilateral trade and foreign direct investment (FDI) between Brazil, China, and India have expanded. Like for Brazil, for a number of Latin American countries, China is the largest 
export market and one of the primary foreign investors. China has become a major provider of loans to Latin American countries, mostly Venezuela, Brazil, and Argentina. Despite enormous geographical distance between Latin America and China (for example, nearly 10,500 miles, as the crow flies, between Brasilia and Beijing), these loans have enabled economic proximity to China. This economic proximity has resulted in political proximity as well. China's relationship with Latin America is fundamentally changing the nature of Latin America's export structure and performance, with open acceptance and encouragement of the country's government. Through its loans and FDI China is profoundly affecting the region's economy (Fung, Garcia-Herrero, \& Seade, 2015; Wise \& Myers, 2017).

In 2019, Brazil, China, and India are co-designing a number of FDI and international trade partnerships. There has been an increased effort to explore complementarities through a greater cooperation and collaboration between Brazil, India, and China's economies. These three countries will be at the center of global economic events in the next decades. Brazil's increased economic proximity to both China and India will offer the opportunity to increase Brazil's integration into the global economy. In 2019, Brazil expects to attract close to USD 80 billion worth of FDI. Both China and India are aiming for an increased share of incoming FDI for Brazil. Brazil's relations with both China and India encompass cooperation agreements in areas as innovation and technology. Nevertheless the main thrust of this relationship has been in the areas of international trade and FDI (Abdenur, 2013; Dosch \& Goodman, 2012; Frias \& Coelho, 2018).

The rapid growth of India's and China's economies offers not only Brazil but also the rest of Latin American countries opportunities in terms of exporting to India and China's growing domestic markets. This trade relationship often engenders opportunities in terms of higher levels of FDI and capital flows from these two countries. The level of economic interdependence between China and Latin America countries, especially Brazil, has substantially increased in the past two decades. The level of integration between China and Latin America is such that a $1 \%$ decline in China's GDP growth implies a $0.6 \%$ reduction in Latin America's GDP growth rate (Esteban, 2016; Jank, 2015; Lederman, Olarreaga, \& Perry, 2007; Powell, 2017).

Table 1 provides a summary of the main economic and social indicators for Brazil, China, and India. China and India have the largest population, 1.4 and 1.3 billion persons, respectively, showcasing an attractive domestic market, given the emerging middle class in these two countries. Brazil has also expanded its middle class, becoming the target for a number of China's and India's multinationals as well. China has by far the more dominant economy with a nominal GDP of USD 14 trillion, followed by India with a nominal GDP of USD 2.8 billion, and Brazil with a nominal GDP of USD 2 billion. China is also the dominant exporter, with revenues in the range of USD 2.26 trillion, almost ten times Brazil's exports. All three countries, however, did not fare well when it comes to corruption. The Corruption Perception Index, as reported by Transparency International, 
Table 1. Basic statistics—China, India, and Brazil.

\begin{tabular}{lccc}
\hline & China & India & Brazil \\
\hline 1. Population in billions (2017) & 1.4 & 1.3 & 0.209 \\
2. GDP Nominal, USD trillion (2017) & 14 & 2.8 & 2 \\
3. Exports. USD trillion (2017) & 2.26 & 0.302 & 0.217 \\
4. Corruption Perception Index (2017 Rank) & 77 & 81 & 96 \\
5. Human Development Index (2017 Rank) & 90 & 131 & 79 \\
6. Economic Freedom Index (2017 Rank) & 110 & 130 & 153 \\
7. Innovation Index (2017 Rank) & 22 & 60 & 69 \\
8. Competitiveness Index (2017 Rank) & 27 & 40 & 80 \\
9. Ease of Doing Business (2017 Rank) & 78 & 100 & 125 \\
\hline
\end{tabular}

Sources: World Bank, 2018; CIA, 2018; Transparency International, 2018; United Nations, 2018; World Economic Forum 2018; The Heritage Foundation 2018.

ranks China as 77 th, India as 81 st, and Brazil as 96 th, out of 185 countries. High levels of corruption tend to deeply affect a country's economic, social, and political environments, deeply affecting transparency and effective governance. All three countries also show a poor performance as measured by the Human Development Index (HDI), reflecting the low-status of health care and the overall social situation. As reported by the United Nations, China ranked 90th, India 131st, and Brazil 96th. Low HDI levels constitute a major bottleneck for the further sustainable development of these countries, since poverty tends to affect the overall governance of a country. These three countries also show high-levels of government interference in their economies. The Economic Freedom Index (as calculated by the Heritage Foundation) ranks all three of these countries very low.

Moving forward, the private sector needs to be the engine of growth for these economies, not the government. The economic policies of these countries are also crowding out the emergence of a healthy private sector. China, more than India and Brazil, understands the role of innovation in promoting a more competitive and creative economic environment. As reported by World Intellectual Property Organization (WIPO), in 2017, China had the world's 22nd most innovative economic environment, followed by India's ranked at 40th, and Brazil's 69th. Increased levels of innovation, in addition to a number of other economic and social variables, tend to result in more competitive economic environment. Moreover, as reported by the World Economic Forum, China has become a much more competitive economy in the past decade, ranking 27th in the world in 2018, followed by India, ranked 40th, and Brazil, which has shown declining rates of competitiveness in the last decade, thereby ranking 80th in the world. The World Bank's "Ease of Doing Business Report" also shows that all three countries need to improve the quality of their business environments. China was ranked 78th, India 100th, and Brazil 125th. Brazil has shown signs of deteriorating quality in its business environment. Rampant corruption has deeply affected 
Brazil's business, social, political, and economic environments. The three countries are not creating a very favorable environment for the emergence of a healthy private sector. Some of these characteristics are difficult to accept or interpret. India has remained ruled by the inheritance of British legal jurisprudence, has remained a vibrant democracy, guarantees and secures fundamental rights of its citizens, has adapted to "western" outlook while retaining age-old culture (without going through a cultural revolution), and has younger population. China does not have these advantages. India has numerous drawbacks. It recognizes over 22 official languages, including English, is an utterly heterogeneous population in terms of ethnicities, races, color, religions, and languages. It has inherited from the colonial rulers a burdensome, vast bureaucratic structure, which has become ossified. China does not have these disadvantages.

The paper is organized as follows. Section II examines the relationship with China. Section III examines the relationship with India. Section IV examines trade among three countries. Section $\mathrm{V}$ examines the issues of asymmetry in relationships. Section VI concludes the paper by mentioning the limitations of the present study and the scope for further study.

\section{China}

China's economic interactions with Latin American countries have taken the form of international trade transactions, FDI, and loans. Over the past two decades, China has become a vital trading partner for Latin American countries. For instance, in 2016, Latin American exports to China amounted to USD 103 billion, and imports from China amounted to USD 113 billion, indicating a very dynamic and meaningful trade relationship. In a very short period of time, China has become the top destination for South American exports and the second most important destination to Latin American exports, second only to the U.S. (Creutzfeldt, 2016; Lin \& Wang, 2016).

In 2016, China purchased close to $22 \%$ of all Latin American extractive exports. China is replacing the U.S. as the major destination for Latin American exports of extractive products. Latin American main extractive exports to China are petroleum, iron ores and concentrates, copper ores and concentrates, and copper. These four commodities, along with soybeans, dominate exports to China, accounting for close to two-thirds of all Latin American exports to China. On the other hand, China's exports to Latin American countries show a much more diversified array of products. For instance, the top Chinese exports to Latin American countries are telecommunication equipment, data processing machines, optical instruments, ships and boats, and electrical equipment. These five products account for close to $23 \%$ of China's exports to Latin American countries (Miner, 2017; Ray \& Gallagher, 2017).

Chinese FDI operations in Latin America are in the form of Mergers and Acquisitions (M\&A) or Greenfield FDI (GFDI), i.e., investment in new assets. In 2016, China invested USD 12.4 billion in Mergers and Acquisitions and USD 3.3 billion in Greenfield FDI. Between 2011 and 2016, most of the M\&A activity was 
in the extractive industry (close to 59\%), followed by utilities. Chinese Greenfield FDI were mostly in manufacturing, at 32\%, followed by extraction and refining, finance, and utilities (The Economist Intelligence Unit, 2016).

It is important to note that even though China has become a large player in Latin American markets, its share of total M\&A and Green Field investments in Latin American markets is still below other traditional investors. For instance, between 2011 and 2016, total M\&A investments in Latin America amounted to USD 288.9 billion compared to China's USD 27.9 billion. Total GFDI in Latin America during the same period 2011-2016 amounted to USD 376.2 billion, and China's total GFDI in the same period amounted to USD 25.6 billion (Hornby et al., 2017).

China has also provided loans to a number of Latin America's top extractive companies. In Brazil, China's Development Bank extended a USD 15 billion loan to Petrobras and close to USD 2 billion to the Venezuelan State controlled oil company Petróleos de Venezuela, S.A. (Maximo, 2017).

China has plans to expand its exports of knowledge-intensive products to Latin American markets. By providing loans and investing in areas such as energy, logistics, and infrastructure, the region will become an important market for Chinese-made locomotives, engineering machinery, and new energy equipment (Contipelli \& Picciau, 2015).

Brazil has become China's second largest destination for infrastructure related FDI in the world. Since 2015, China's companies have acquired close to twenty-one Brazilian-owned companies, totaling close to USD 21 billion. In 2017, Chinese investments accounted for almost $30 \%$ of all investments in infrastructure in Brazil. In 2017, China spent close to USD 20 billion in Brazil, a 90\% rise in comparison to 2016. For instance, close to $80 \%$ of Chinese global infrastructure investments were directed to Brazil's energy sector. Chinese multinationals, such as State Grid Corporation of China, China Three Gorges Corporation, China Communications Construction Company Limited, and Shanghai Pengxin Group Company Limited, are major investors in Brazil's energy sector. Note, however, that the first three (State Grid, Three Gorges, and Communications Construction) are state-owned, i.e., they are owned and operated by State-Owned Assets Supervision and Administration Commission of the State Council (SASAC). Its website (http://en.sasac.gov.cn/) states the following: "The State-owned Assets Supervision and Administration Commission of the State Council (SASAC) is an institution directly under the management of the State Council. It is an ad-hoc ministerial-level organization directly subordinated to the State Council. The Party Committee of SASAC performs the responsibilities mandated by the Central Committee of the Chinese Communist Party." Further, the Belt and Road Initiative is under the supervision of SASAC. Therefore, in the case of Chinese trade and investment, economic proximity is closely aligned with political proximity (Moreira, 2015; Barrucho, 2017).

Lately, an increased attention is being lavished on Brazil's service industry, 
especially in the areas of energy generation and distribution. China has prioritized M\&A activity in the Brazilian market over Greenfield operations. China has taken steps to facilitate the penetration of its own companies within the Brazilian market. For instance, a number of Chinese banks, such as Industrial and Commercial Bank of China (ICBC) which has become one of the largest commercial banks in the world, and China Development Bank (CDB), are now operating in Brazil. Note again that these two entities are state-owned. The most important and largest state-owned institution for the promotion of foreign trade, China Council for the Promotion of International Trade (CCPIT), co-named China Chamber of International Commerce (CCOIC) in 1988, is now operating in Brazil. These establishments facilitate further penetration by Chinese companies in Brazil's economy (SEAIN, 2018).

Brazil's decision to increase the participation of multilateral agencies and foreign banks in its infrastructure projects allows for further participation of Chinese Banks in Brazil's market. For instance, China's banks and China Export \& Credit Insurance Corporation (Sinosure) are financing a wind farm in Brazil's Northeast region. Sinosure's website states the following: "Sinosure is a state-funded and policy-oriented insurance company established and supported by the state to promote China's foreign economic and trade development and cooperation." The increasing participation of China's state-owned companies in Brazil's energy sector is expected to attract additional financial companies from China and elsewhere to Brazil's capital market. China and Brazil's governments are also creating a USD 20 billion fund to invest in Brazil's infrastructure projects (Rosa, 2017).

China's FDI in Brazil has gone through different phases and cycles. China's appetite for raw materials and commodities drove its initial investments in Brazil. Investment by Sinopec Limited (one of three state-owned national oil companies) in Brazil's oil and gas industry illustrates this first phase.

The second phase was marked by China's drive to substitute exports of manufactured products by local production. Companies in the transportation, machinery, and electronics industries represent this second phase of Chinese investments in the Brazilian market. Companies such as Gree Electric, dominantly-owned by Gree Group, which in turn is 100-percent owned by Zhuhai city government, set up manufacturing of electrical appliances in Brazil's Export Processing Zone in Manaus (Correio da Amazonia, 2017; Maia \& Polito, 2017a; 2017b).

The third phase of the Chinese FDI was directed toward Brazil's financial markets. For instance, China Construction Bank (CCB) plans to meet the needs of more than 200 Chinese companies currently operating in Brazil. CCB is one of the big four banks in China and is owned by the Chinese government holding company, Central Huijin Investment Company. The Chinese company Huayang (relying on state's funds and own funds), created a USD 3 billion investment fund to facilitate Chinese investments in Brazil (or Brazilian investments in 
China). This is an important dimension of China's exports of "capital" to emerging markets, such as Brazil (FIESP, 2017).

Brazil is planning to privatize close to 20 Gigawatts (GW) of electricity generation, the equivalent of two Belo Monte hydro power plants. Chinese companies, such as Three Gorges and State Grid, are potential investors. Both companies have already made substantial investments in Brazil's energy sector. The Chinese conglomerate HNA Group has expanded its investment in Brazil. In 2015, it acquired almost a quarter participation in Brazil's Azul Airline and also the control of Rio de Janeiro's international Airport Galeao. In 2020, however, the provincial Hainan government took control of HNA Group. HNA Group is in bankruptcy proceedings and the accountants and attorneys are spending countless hours trying to unravel the web of HNA Group's over-2000 subsidiaries, affiliates, and shell companies. HNA Group has an outstanding debt of about USD 110 billion causing cash-flow problems (Mantoan \& Pires, 2017).

In 2018, Chinese FDI in Brazil was reduced by $75 \%$ in comparison to 2017 levels, around USD 2.7 billion. Bolsonaro's election and his negative comments about the role of China in Brazil's economy and business environment made Chinese companies take a more cautious approach to Brazil. Bolsonaro's comments about the increasing role of Chinese companies in key Brazilian industries is raising concerns in China. However, Bolsonaro's privatization and concessions' program will certainly set the tone for how Chinese companies will approach the Brazilian market. Still, the Brazilian-China Chamber of Commerce (CEBC) indicates that there are currently 31 projects in the pipeline for 2019, demonstrating China's commitment to Brazil's economy (Cariello, 2018; Conselho Empresarial Brasil-China (CEBC), 2017).

\section{India}

Brazil and India established formal diplomatic relations in 1948, soon after India's independence in August 1947. Nevertheless informal relations between the two countries were mainly in agriculture through the conduits of the Portuguese who had numerous colonies in India and private individuals. Take three most prominent examples: Cashew, a tree native of Eastern Brazil, was brought to India in the 16th century and was used to prevent coastal soil erosion. The largest edible fruit, jackfruit (jaca in Portuguese), originated in South Asia, and was introduced into Brazil and is cultivated throughout the tropical regions of the country. (For the sake of completeness, we should note that jaca is actually an invasive non-native species). Brazil imported between 1870 and 1962 a total of 6262 Zebu animals, with fewer than 700 being "gir" cattle. The fortunes of the Brazilian dairy industry changed in 1960 when Maharaja of Bhavnagar, Gujarat, Krishna Kumarsinh Bhavsinh gifted a "gir" cattle pair to Celso Garcia Cid, a well-known Brazilian cattleman. This gir bull started a genetic revolution as it spawned a mixed breed. This gir was cross-bred with Holstein to develop the hybrid "Girolando". Another breed strain ("Ongole") from India led to the de- 
velopment of the Brazilian "Nelore" breed. Brazil continues to import fresh embryos from India to rejuvenate its cattle breed (Santana et al., 2014).

However, the cold war kept the two countries from developing a closer relationship until the early 1990s. In the 1990s, Brazil and India reestablished economic and scientific ties. In the early 2000s, a new cycle of cooperation and collaboration was developed between the two nations. Several agreements were signed, aiming at deepening bilateral cooperation to promote common socio-economic development agendas. For instance, India and Brazil signed the "Investment Cooperation and Facilitation Treaty," advocating for businesses in India to invest and trade with Brazil and vice-versa, which should facilitate bilateral trade and investment. Equally, if not more, important was an MOU signed in 2016 between the Department of Animal Husbandry, Dairying and Fisheries (DADF) (a department in the Ministry of Agriculture) and Brazilian Agricultural Research Corporation (Embrapa) for cooperation in the fields of Zebu Cattle Genomics and Assisted Reproductive Technologies. In 2018, another MOU was signed for Indian import of doses of frozen gir bull semen from Brazil (ApexBrasil, 2012; Frazao, 2016; Seshasayee, 2018).

Since 2012, Brazil and India started to develop closer economic and business ties resulting in a multitude of agreements, such as cooperation in the field of biotechnology and in other dimensions of science and technology. These two economies are highly complementary. Brazil has a number of natural resources and is a major producer of commodities. India is a powerhouse in software and knowledge-driven services. India is also an innovator, providing products and services to the lower levels of its pyramid (Kuwayama, 2012; Prasad \& Chakraborty, 2012).

Trade between Brazil and India has expanded over the past two decades. India exports mineral fuels, mineral oils and products, organic chemicals, pharmaceutical products, iron and steel, and plastics to Brazil. Brazil exports ores, mineral fuels, iron and steel, organic chemicals, raw hides and skins, and precious/semiprecious stones to India. It is clear that natural-based resource goods dominate India and Brazil's trade (The Dollar Business, 2018).

Several products have been excluded in the bilateral trade agreement between India and the South American Economic Organization (Mercosur), such as textiles, clothing, automobiles, and auto-parts. These reflect both countries' sensitive sectors. Similar sensitiveness will be faced in the agricultural sector, where India has been notoriously protective of its farming sector. Thus, the competitiveness of Mercosur countries in food-processed products cannot be fully explored in the relationship with India. By 2016, India had close to USD 5 billion invested in Brazil and bilateral trade amounted to USD 6.6 billion.

Foreign direct investment between India and Brazil is dominated by a few sectors. Brazilian companies in India have invested in India's auto industry, IT, mining, energy, biofuels, and footwear. India's companies in Brazil have invested in pharmaceuticals, energy, agri-business, mining, engineering/auto sectors. For instance, the Brazilian company Marcopolo, S.A. and India's Tata Motors have a 
joint-venture to assemble buses in their Dharwad plant, albeit the 14-year old joint-venture is expected to end when the Brazilian company exits in 2021. In 2007, Brazil's steel maker Gerdau entered into a joint-venture with India's Kalyani Steels Ltd. to acquire SJK Steel Plant Ltd. with an equal partnership of 45\% each in Tadipatri unit. In 2013, Gerdau acquired Kalyani's share and became the majority stake-holder at 99.5\%. In 2006 Brazil's state-owned oil company Petroleo Brasileiro S.A. (Petrobras) signed agreements with India's state-owned oil company Oil and Natural Gas Corporation (ONGC) to explore oil and natural gas in India, Brazil and other countries. Indian information-technology companies have established themselves in Brazil. Wipro is operating in Brazil to provide services to local companies. In 2002 Tata Consultancy Services (TCS) developed a joint-venture, TCS do Brasil, with the Brazilian company Grupo TBA, and in 2007 bought out the share of Grupo TBA. In 2013, Mahindra Satyam bought a 51\% stake in Brazil's Comples IT. A number of multinationals from India, such as Mahindra and Mahindra, Shree Renuka Sugars, Videocon Industries, and ONGC, are present in Brazil's domestic market. India's companies have invested in Brazil's auto-industry, mining, energy, IT, pharmaceuticals, and agri-business, among other industries (Oliveira, 2018; Banco Central do Brasil, 2018).

India multinationals such as Mahindra and TVS Motor Companies are selling SUVs, tractors and motorcycles in Brazil. In 2011 the Indian company United Phosphorus Limited (UPL) invested in a 50\% stake in an agro-chemical company, Sipcam Isagro Brasil (SIB), in Brazil. Infrastructure projects have also attracted Indian companies. For example, Sterlite Power Grid is mimicking Chinese companies in investing in Brazil's infrastructure projects. In 2017, Wipro acquired the Brazilian company InfoServer. The acquisition will allow Wipro to gain market share in Brazil's financial markets (Brigatto, 2017; Costa, 2017).

There are numerous opportunities in India's market for Brazilian companies in the areas of biodiesel, infrastructure, ethanol, and water management. Brazil could offer its knowhow and technology in the areas of agribusiness and food-processing, mining, bio-fuels, oil exploration, and nuclear power. India, on the other hand, could offer green energy technologies, solar and wind, and bulk drugs for medicine.

One of the distinguishing characteristics of India has been its increasing share of services in its economy and the increase in exports of services to global markets. The global expansion of the digital economy, lower commercial trade barriers, and the increasing share of services in global trade has allowed India to develop a globally competitive service industry.

Both Brazil and India played meaningful roles in their own respective regions. Brazil is an active member of Mercosur and the Latin American Integration Association (ALADI), whereas India belongs to South Asian Association for Regional Cooperation (SAARC) and the Bay of Bengal Initiative for Multi-Sectoral Technical and Economic Cooperation (BIMSTEC), and has also developed links to Association of Southeast Asian Nations (ASEAN) group of nations. Brazil and India share a number of common goals and aspirations in the global economy. 
Both countries have democratic political regimes; both are members of G-20 and signatories of some other multilateral agreements. Given these common interests, India perceives Brazil and other Latin American countries as offering their economies as strategic markets for its manufactured products and services. Perceived under-valued currencies and lower asset pricing are cited by India's multinationals as drivers for its FDI in the region (Bachelet, 2021).

\section{Intra-Bic Trade}

Intra-Bic trade has been growing steadily since the early 2000s. This section discusses the recent evolution of trade between Brazil, China, and India. Data obtained to create Figure 1 and Figure 2 were obtained by the authors from Brazil's Trade agency, viz., The Secretariat of Foreign Trade (SECEX). The figures help to illustrate the flows of trade between Brazil, China, and India. Moreover, it helps to better understand the structure of trade between these three countries (Sinate, Fanai, \& Bangera, 2016; Valor, 2017).

From 2000 to 2017, Brazil's total exports expanded from USD 55.1 billion to USD 217.7 billion. During the same period, Brazil's exports to India expanded from USD 217 million to USD 4.6 billion. Brazil's exports to China expanded even

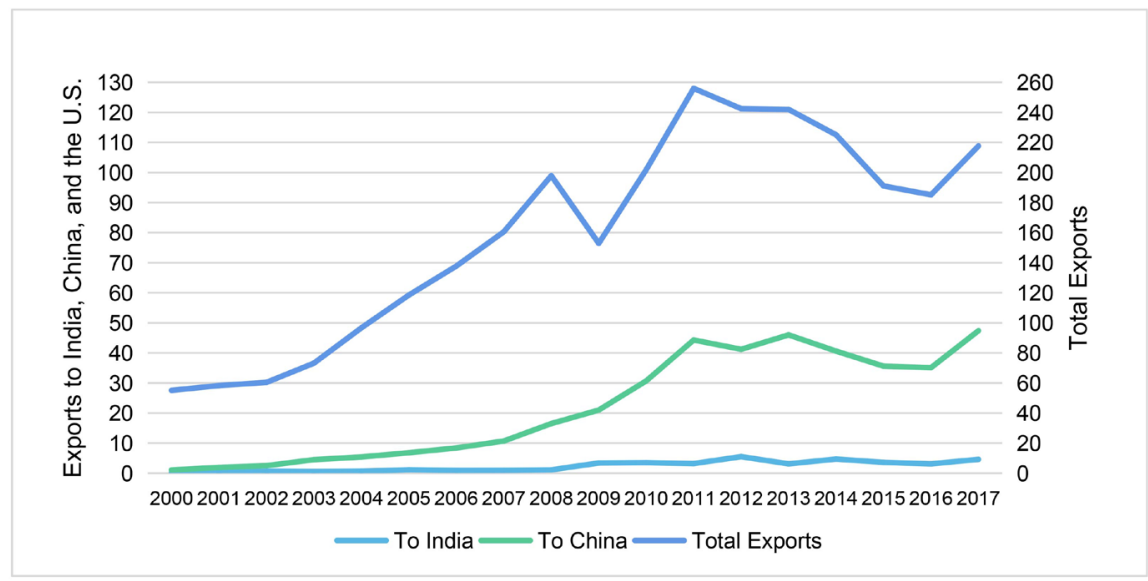

(a)

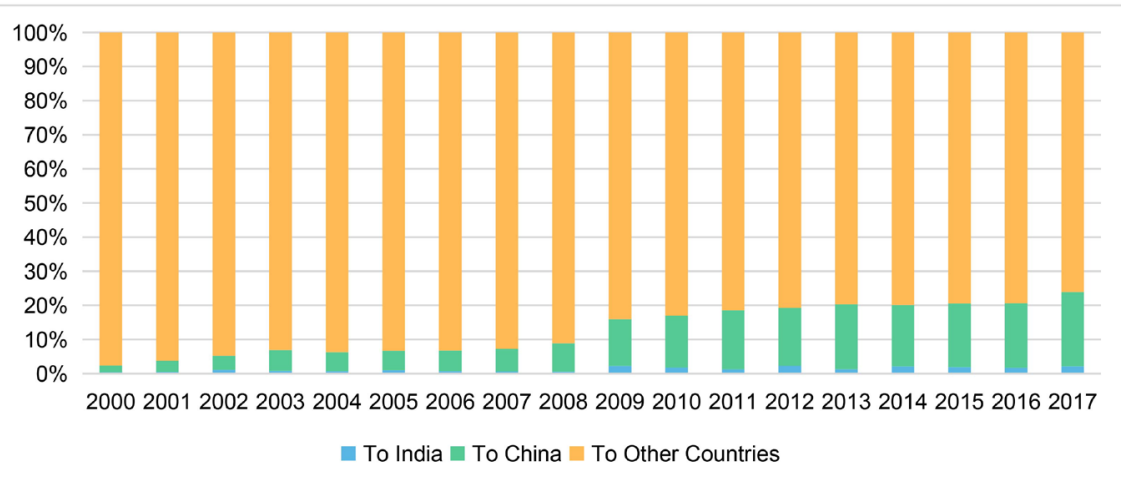

(b)

Figure 1. (a) Brazilian exports, 2000-2017 (in \$BN); (b) Destinations of Brazilian exports, 2000-2017. 


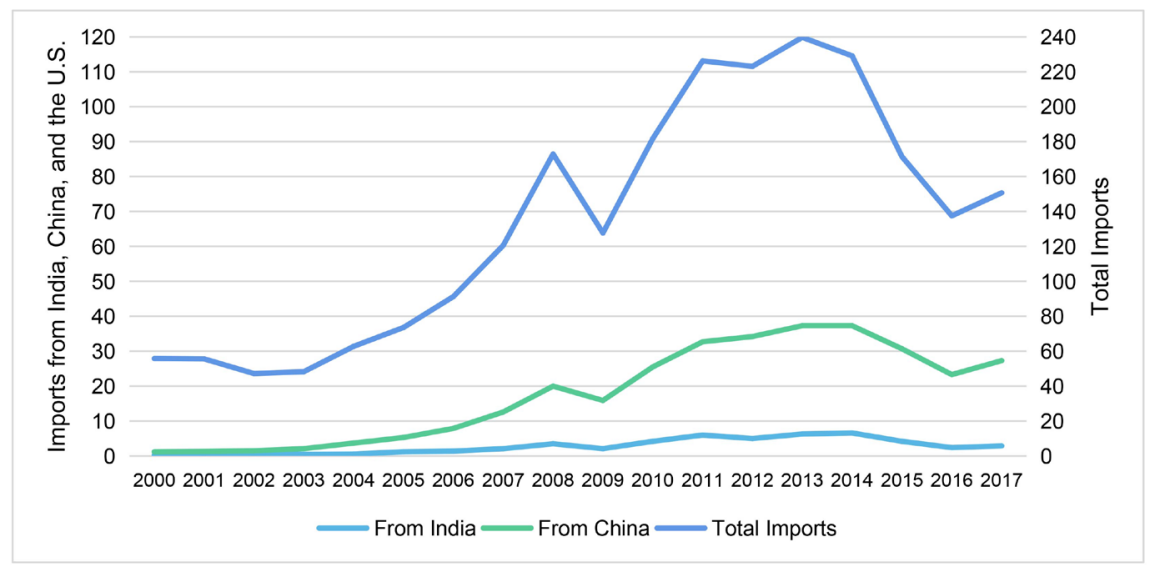

(a)

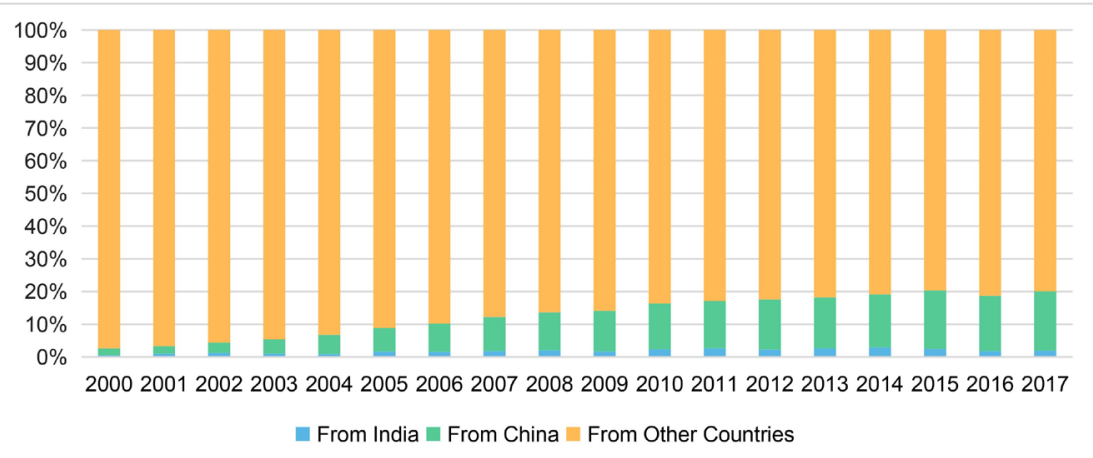

(b)

Figure 2. (a) Brazilian imports, 2000-2017 (in \$BN); (b) Sources of Brazilian imports, 2000-2017.

more profoundly, from USD 1.1 billion in 2000 to USD 47.4 billion in 2017. During this period, China accounted for $14 \%$ of Brazil's total exports, jumping from $2 \%$ in 2000 to about $22 \%$ in 2017 . In contrast, India accounted for only $1.4 \%$ of Brazil's total exports of the same period, growing from less than $0.4 \%$ in 2000 to a little more than $2 \%$ in 2017 . It is worth noting that the average annual growth rates in Brazil's exports to China (27.7\%) and India (31.2\%) are much higher than that of the total exports $(9.7 \%)$. This pattern confirms the observation that Brazilian exports have been finding increasingly larger markets in China and India as these two Asian countries experience historic economic booms in the past two decades. Figure 1(a) and Figure 1(b) show the evolution of Brazil's exports to China and India in the period under analysis.

On the import side, China accounted for close to $13 \%$ of all of Brazil's imports during the 2000-2017 period, whereas India accounted for 2\% of Brazil's total imports. Brazil's economic recession showcases the declining import volumes from both China and India after 2013.

Overall, during the period 2000-2017, Brazil showed a trade surplus with China in the amount of USD 80 billion and a trade deficit of USD 9 billion with India during the same period. Also important to note is that Brazil's share of China's total imports for 2016 was about $2.9 \%$, and for India's total imports in 
2016 it was close to $1.3 \%$. Clearly, both countries have a much higher share of Brazil's total imports than Brazil has of China's and India's markets. Figure 2(a) and Figure 2(b) illustrate this evolution over the period under analysis. Brazil needs to stress the exports of its own industrialized products to both China and India. To deepen the relationships and increase the bilateral trade, China especially would do well to stop imposing protectionist measures on higher value-added products from Brazil.

The structure of trade established with both China and India is another important dimension of Brazil's trade relationship with both countries. Table 2 and Table 3 break down Brazil's exports to and imports from China and India into primary and industrialized goods.

In 2000, close to $68 \%$ of all of Brazil's exports to China were made of primary products, and only $32 \%$ of industrialized products. India, on the other hand, had

Table 2. Breakdown of Brazil's exports to China and India by primary and industrialized products.

\begin{tabular}{|c|c|c|c|c|c|}
\hline \multicolumn{6}{|c|}{2000 Exports } \\
\hline \multirow{2}{*}{ To: } & \multirow{2}{*}{$\begin{array}{c}\text { Total Value } \\
\$ B N\end{array}$} & \multicolumn{2}{|c|}{ Primary Products } & \multicolumn{2}{|c|}{ Industrialized Products } \\
\hline & & $\$ B N$ & $\%$ & $\$ B N$ & $\%$ \\
\hline China & 1.07 & 0.73 & $68 \%$ & 0.34 & $32 \%$ \\
\hline India & 0.21 & 0.02 & $12.4 \%$ & 0.19 & $87.6 \%$ \\
\hline \multicolumn{6}{|c|}{2017 Exports } \\
\hline \multirow{2}{*}{ To: } & Total Value & \multicolumn{2}{|c|}{ Primary Products } & \multicolumn{2}{|c|}{ Industrialized Products } \\
\hline & $\$ \mathrm{BN}$ & $\$ B N$ & $\%$ & $\$ B N$ & $\%$ \\
\hline China & 47.4 & 41 & $87 \%$ & 6.4 & $13 \%$ \\
\hline India & 4.5 & 2.2 & $48.9 \%$ & 2.3 & $50.9 \%$ \\
\hline
\end{tabular}

Source: Secretaria de Comercio Exterior, Brasilia.

Table 3. Breakdown of Brazil's imports from China, India, and the U.S. by primary and industrialized products.

\begin{tabular}{|c|c|c|c|c|c|}
\hline \multicolumn{6}{|c|}{2000 Imports } \\
\hline \multirow{2}{*}{ From: } & \multirow{2}{*}{$\begin{array}{c}\text { Total Value } \\
\$ B N\end{array}$} & \multicolumn{2}{|c|}{ Primary Products } & \multicolumn{2}{|c|}{ Industrialized Products } \\
\hline & & $\$ B N$ & $\%$ & $\$ B N$ & $\%$ \\
\hline China & 1.22 & 0.1 & $8 \%$ & 1.12 & $92 \%$ \\
\hline India & 0.27 & 0.008 & $3 \%$ & 0.262 & $97 \%$ \\
\hline \multicolumn{6}{|c|}{2017 Imports } \\
\hline \multirow{2}{*}{ From: } & Total Value & \multicolumn{2}{|c|}{ Primary Products } & \multicolumn{2}{|c|}{ Industrialized Products } \\
\hline & $\$ B N$ & $\$ B N$ & $\%$ & $\$ B N$ & $\%$ \\
\hline China & 27.2 & 0.6 & $2 \%$ & 26.6 & $98 \%$ \\
\hline India & 2.75 & 0.05 & $1 \%$ & 2.7 & $99 \%$ \\
\hline
\end{tabular}

Source: SECEX: Secretaria de Comercio Exterior, Brasilia. 
close to $87 \%$ of its imports from Brazil made of industrialized products. In 2017, the share of primary exports in Brazil's total exports to China increased to $87 \%$ and the share of industrialized exports declined to $13 \%$. The increasing share of primary products tends to cause a deterioration in Brazil's terms-of-trade with China. In 2017, Brazil's exports to India showed a balance between primary product exports and industrialized products. Consequently, India's markets seem "friendlier" to Brazil's exporters of high value-added products.

On the import side, in 2000 Brazil's imports from China consisted mostly of industrialized products, $92 \%$. In the case of India, 97\% of Brazil's imports were made of industrialized products. In 2017, Brazil also showed a concentration on imports of industrialized products from both China and India. Clearly, Brazil has become an appealing market for industrialized exports from both China and India. Brazil has also been specializing in the exports of primary products for both China and India.

\section{Concerns on Asymmetries}

There are several characteristics permeating Brazil's trade relationship with China. First, the trade with China tends to be a good example of asymmetric relationship, where China exports high-value-added products to Brazil whereas in return Brazil exports natural-resource-based goods. Thus, terms-of-trade tend to favor China's side. One may counter this by claiming that this pattern of trade actually reflects comparative advantage and factor endowments of China and Brazil. The percentage of Brazilian-made manufactured exports to the Chinese market observed a sharp decline between 1989 and 2018. For instance, in 1989, more than $60 \%$ of Brazilian exports to the Chinese market were made of manufactured products. In 2018, three commodities (soybeans, petroleum, and iron ore) accounted for $80 \%$ of Brazil's exports to China. Interestingly enough, both policy-makers and the private sector in Brazil failed to design strategies to reverse this trend. China's expanding middle class should certainly have a positive impact on Brazil's exports of manufactured goods. The task will be up to Brazilian policy-makers and Brazil's private sector to increase the exports of valued-added goods to China (Zafalon \& Mauro, 2019).

Nevertheless, these asymmetric trade flows or the low penetration of Brazilian-made products and services in the Chinese market reflects Brazil's business environment bottlenecks represented by poor infrastructure, faulty logistics, lack of education, stifled innovation, under-developed technology infrastructure, and high taxes. Brazil's export profile, in its trade relationship with both India and China, is largely a reflection of its own domestic economic and business shortcomings, leading to the increasing costs of doing business in Brazil. The World Bank ranks Brazil 125th out of 190 countries in the "2018 Ease of Doing Business" category, exposing the hardships faced by Brazilian companies when designing long-term strategies (World Bank, 2018).

The increasing apparent economic and political proximity of China to Brazil 
is raising numerous concerns. For instance, China has continued its mercantilist approach to international trade with a vehemence that puts the counter-parties in untenable and compromised position. On Brazil's side, however, the lack of a clear trade strategy and a fair, balanced trade diplomacy to engage and further penetrate the Chinese markets is preventing Brazil from moving away from a "neo-colonial" trade relationship with China. Second, Brazil and the rest of Latin American countries are not a main destination for China's exports, yet China is a primary market for Brazil. This is not very advantageous in terms of a negotiation position with China. Brazilian exports of raw materials and commodities to China raise concerns about their impact on job creation and on environmental deterioration, such as deforestation and greenhouse emissions (Fung \& Garcia-Herrero, 2012).

Moreover, China willingly provides attractive loans and large FDI to Latin American countries through its state-owned financial institutions and joint-ventures with state-owned companies. The state-owned enterprises, all under the supervision of the State-Owned Assets Supervision and Administration Commission of the State Council (SASAC), do and are expected to support the Party line. This explicit and implied connection has led to a political proximity, which was previously available only to the U.S. and traditional European trade and investment partners as part of colonial rule and Brazil as part of Western culture. Chinese trade and investment in the region may be indirectly buying political influence. This nefarious connection is likely to influence the decisions of policy-makers in the region to the benefit of China's economic and non-economic objectives. In other words, China Inc., is using its economic muscle as a tool to advance its foreign-policy objectives in the region, mimicking crudely steps taken by other global economic powerhouses previously.

China has followed a "State-to-State" negotiation strategy, allowing its political dimension to overlap with its business dimension. This approach further reinforces China's unique approach to Latin American markets, where political alliances take precedence over properly-assessed business transactions. China's engagement with Brazil is predicated on China's calculations about its own food and energy needs and is based on the principles of its Belt and Road Initiative. Even though Amazon region consists of territory in Brazil (mainly), Peru, Colombia and Ecuador, the awarding of Brazil's Amazon region contracts for hydroelectric dams, waterways, roads and railways, and other infrastructure development illustrates China's "State-to-State" approach towards doing business in the region. In 2015 Chinese premier Li Keqiang and Brazilian president Dilma Rousseff signed 35 agreements for Chinese investment of USD 53.3 billion. One of the most important was the "transcontinental railroad", connecting the Brazilian Atlantic coast to the Peruvian Pacific coast.

(https://dialogochino.net/en/trade-investment/2464-china-invests-billions-more -in-brazil/) Whether the contracts would go through bidding process was not clear then and has not been made clear since then. The Chinese interest is clear: The series of power plants and reservoirs would reduce the cost of food exports 
from Brazil to China. Additionally the other infrastructure would connect soybean plantations to the Amazon River, and support many mining programs for various minerals and metals (Gouvea, 2016). Various development schemes involving the Amazon region has Chinese fingerprints. Whereas the earlier Amazon Surveillance System (sivam), later expanded into Amazonian Protection System (sipam), has led to a larger vision represented by Amazon Integration Plan, whereby the government would develop the so-called unproductive Amazon to integrate it into Brazilian, regional and global economy

(https://news.mongabay.com/2019/01/bolsonaro-government-reveals-plan-to-de velop-the-unproductive-amazon/). This accomplishment of this vision would require several years and billions of USD. How much the projects would cost, how the government would finance this set of ambitious projects, what socio-economical and socio-environmental impacts would have been endured are some of the unanswered questions (Trinkunas, 2020).

With the slowdown of China's economy, several Latin American countries are currently experiencing a "Reverse Dutch Disease" effect. The early 2000s saw increasing prices for Latin America's main commodities and natural resource-based goods. One decade later, lower levels of demand for commodities by China demonstrated to Brazil the downside of heavy dependence on the export of commodities. For instance, for countries like Brazil, the appreciation of its currency during the commodity boom hurt its manufactured exports, which are highly sensitive to price increases. The extreme dependence on commodity exports also further penalized investments on innovation and R\&D in the manufacturing sector, compromising Brazil's global competitiveness. Unlike Norway or Chile or Singapore, Brazil never created a "Sovereign Fund" that would allow the Brazilian government to support other sectors of the country's economy during a downturn in the price of its main commodities. The increased dependence of Brazil's economy on China's economy can also be ascertained by the impact of lower growth rates of China's GDP. It has been estimated that lower rates of growth in China are reflected in lower prices for commodities and mineral products in Brazil. It is also estimated that a lower rate of growth for China's economy may lower Brazil's GDP growth by 0.3\% (Martins, 2015; Olmos, 2017).

Some studies have also pointed out the increasing competition of China's products and services on Brazil's exports of manufactured products to traditional third-country markets, such as Argentina and Mexico. Moreover, Brazil has also been losing market share in the U.S. and in European markets as a result of stiffer competition from Chinese manufactured products

It is also important to note that between 1995 and 2016, China was responsible for the creation of 1.8 million jobs in Latin American economies. The large majority of this job creation was related to international trade with China (Barragan, Manuel, \& Aguillera Castillo, 2017; Wang, 2016; Peters \& Armony, 2017; Zhao, 2018).

Such blatant self-serving economic and political influence is largely absent in the Brazil-Indian relationship. The trade is more or less balanced between the 
two countries. As well there appears to be a balance between manufactured goods and commodities and services. Except for Brazilian Petrobras and Indian ONGC, most of the cross-investment has been between private sectors firms of Brazil and India. Both of these countries are largely democratic republics with a history of strong legal climate. The official relationship could have been deeper with a longer history if Brazil had not chosen to ignore India because India was considered to be in the sphere of Soviet influence during the cold war period. Both countries have recognized the importance of the lost period and are trying to make up for it by establishing bilateral relationships in all spheres of human activities.

\section{Conclusion}

The idea that emerging economies would be dominant components of the growth of the world economy was solidified during the mid-1900s and early 2000s. During the first decade of the 2000s, emerging economies had an important role in the growth of the global economy. Increasingly, countries like China and India started to develop a "South-South agenda", when looking for natural resources and markets for its products and services. Brazil, therefore, became a natural trading and investing partner for both India and China. In addition, the three countries have a number of global economic and political aspirations, as demonstrated in their positions during G-20 meetings, deepening the scope of their partnership.

The China-Latin American and Caribbean Countries Cooperation Plan 2015-2019 outlines a number of potential projects and commitments for joint cooperation in manufacturing, agricultural, clean energy, transport equipment, Information and Communication Technology (ICT), transfer of technology, and cooperation in research and development in several areas. If these commitments come to fruition, China and Latin America may be designing a new model of joint economic development-one that would be a clear departure from China's recent strategy of interacting with Latin American markets where Brazil is the largest economy.

Whereas India does not boast of a grand design for the world, Brazil and India have developed a number of agreements that encompass economic and scientific commitments. Both the countries are increasing business, innovation and R\&D interactions.

Thus, both China and India are deepening their overall commitment to Brazil and Latin America through different channels, government sector and private sector, respectively. Brazil and the rest of Latin American countries are expected to take maximum advantage of burgeoning relationships. Gouvea (2016) points out the speed of Chinese influence on defense industry of Brazil and how domestic political and economic policies have moved Brazil's defense industry from incipient major player status to a marginal position in the global defense industry. Clearly, the Chinese influence on one of the most important sectors of 
Brazil has not been in favor of Brazil.

Part of the reason that Brazil and the rest of the Latin American countries have not been able in the past and may not be able in the future to reap benefits from Chinese relationship is domestic social-economic policies burdened by politics and the lack of a strategic economic and business perspective. Brazil must address its main domestic economic, social, and political bottlenecks in order to fully take advantage of closer relations with China and India.

Brazil's traditional "addiction to commodities" in its trade with Asian partners and its reluctance to press for exports of manufactured and knowledge-intensive products and services to both China and India are keeping Brazil from better exploiting both markets. Moreover, the extraordinarily large share of raw materials export to the Chinese market compromises Brazil's ability to further benefit from its trade relations with China because most of the value-added goes to China instead of staying in Brazil. It is a fair question to ask whether China has replaced Portugal as new colonial power. The global "Belt and Road Initiative" pursued by Chinese companies and political policy-makers has resulted in one-sided outcomes. Brazil needs to reevaluate the role China could and would play in Brazil's evolution.

The development of strategic partnerships with India's and China's companies is a vital component in the penetration of these markets by Brazilian companies. The difficulty is that China and India have different economic models. China depends on state-owned companies to a huge degree to spread its influence. India represents a more of a private-sector-led economy. Both economies are substantially closed to foreign companies unless the foreign companies meet some conditions. And, most of the times the conditions imposed in China are onerous.

The deepening of trade agreements between Brazil, India, and China have the potential to further integrate these economies, favoring Brazil's terms-of-trade and allowing Brazil to attract foreign direct investment from both China and India, as well as allowing Brazilian companies to expand their presence in these markets. The signing of the "Investment Facilitation Treaty" between the two countries further facilitate India's investments in Brazil and creates a legal framework for these bilateral investments. Moreover, the growing middle class in all three countries (within the next few decades) promises to increase trade and investments for all three countries involved.

It is clear that all three economies are going to increase their levels of economic interdependence in the next decades. Brazil's new administration is making it very clear that the current "colonial trade" relationship between Brazil and China is under scrutiny. How China and India react to Brazil's increasing scrutiny of trade and FDI will shape the relationship between these three economies in the short term. It is clear, however, that there is a tremendous potential for positive synergies. Therefore, the development of mutually-beneficial strategies will be key determinant in Brazil's relationship to both China and India. Just as India's contribution to Brazilian cattle and dairy industries has helped Brazil 
become a top exporter of beef and producer of milk/milk products, India's contribution to Brazil's agriculture and animal husbandry has been notable. Brazil and India have carved out some share of the space and satellite-launch market, though of late, Brazil seems to have fallen behind India. Space programs of Brazil and India may not be at the same scale and of same scope as that of China; they could still cooperate to increase the joint share. China's space program is more nationalist in nature, designed to win wars. If the international trade and FDI do not result in common benefits, then the policy makers are guilty of abandoning national interest.

The bilateral and trilateral relationships between Brazil, India and China are ripe for a deeper examination. This article represents a first step in formulating concepts for further study, thereby limiting the scope of its study. More quantitative study of trade and FDI is necessary to understand the dynamics of the relationships. As the countries evolve and take their political, economic and social systems in separate directions, longitudinal studies would become possible. The trade- and FDI-related data are more readily available than the data on social development, which, however, can be approximated by using Human Development Index. Thus, much work awaits the current authors.

\section{Conflicts of Interest}

The authors declare no conflicts of interest regarding the publication of this paper.

\section{References}

Abdenur, A. (2013). Brazil's Trade with Asia; Key Drivers and Challenges Ahead. Paper Presented at the Conference "Reaching Across the Pacific: Latin America and Asia in the New Century”. Washington DC, 20 June 2013, 1-25.

Amorim, O. (2006). Presidencialismo e Governabilidade nas Americas. Fundacao Getulio Vargas Konrad Adenauer.

ApexBrasil (2012). India: Perfil e Oportunidades Comerciais. Apex-Brasil.

Bachelet, P. (2021). Can India Become Latin America's Next Trade Frontier? http://www.iadb.org

Baer, W. (2013). The Brazilian Economy: Growth and Development. Lynne Rienner Publishers, Inc.

Banco Central do Brasil (2018). Relatorio de Investimento Direto no Pais. Banco Central.

Barragan, G., Manuel, J., \& Aguillera Castillo, A. (2017). China and Latin America: Strategic Partners or Competitors? Revista Escuela de Administracion de Negocios, No.82, 1-23. https://doi.org/10.21158/01208160.n82.2017.1642

Barrucho, L. (2017, August 31). Na China, Temer quer vender Brasil. http://www.uol.com.br

Brigatto, G. (2017 Januaru 25). Indiana Wipro, de servicos de tecnologia, compra Brasileira InfoServer. http://www.valor.com.br

Cariello, T. (2018, December 22). Brasil-China, Grandes Negocios (pp. A.2). O Estado de Sao Paulo. 
CIA (2018). The World Factbook. http://www.cia.gov/

Conselho Empresarial Brasil-China (CEBC) (2017). Investimentos Chineses no Brasil. Conselho Empresarial Brasil-China.

Contipelli, E., \& Picciau, S. (2015). China's Global Order: A New Paradigm in South to South Relations. CIRR, 21, 89-108. https://doi.org/10.1515/cirr-2015-0012

Correio da Amazonia (2017, July 20). Fieam Busca Parceria com a China para Investimentos no AM. Correio da Amazonia. http://www.correiodaamazonia.com

Costa, L. (2017, November 13). Indianos vem Fortes para leilao de Linhas de Energia no Brasil. http://www.reuters.com/

Creutzfeldt, B. (2016). China and the U.S. in Latin America. Revista Cientifica General Josae maria Cordova, 14, 23-40. https://doi.org/10.21830/19006586.1

Danns, G., \& Danns, D. (2017). Sharing or Taking? Analyzing China's Economic Relations with Latin America and the Caribbean. Journal of Business \& Economic Policy, 4, 20-29.

De La Torre, A., Didier, T., Ize, A., Lederman, D., \& Schmukler, S. L. (2015). Latin America and the Rising South: Changing World, Changing Priorities. World Bank. https://doi.org/10.1596/978-1-4648-0355-0

Dieppe, A., Gilhooly, R., Han, J., Korhonen, I., \& Lodge, D. (2018). The Transition of China to Sustainable Growth. Occasional Paper Series No.206. European Central Bank.

Dollar, D. (2017). China's Investment in Latin America. Geoeconomics and Global Issues, Paper 4, The Brookings Institution.

Dosch, J., \& Goodman, D. (2012). China and Latin America: Complementarity, Competition, and Globalization. Journal of Current Chinese Affairs, 41, 3-19. https://doi.org/10.1177\%2F186810261204100101

Economy, E. (2018). The Third Revolution: Xi Jinping and the New Chinese State. Oxford University Press.

Esteban, M. (2016 July 11). China: A Partner for the Development of Latin America? Expert Comment 33/2016. http://www.realinstitutoelcano.org

FIESP (Federação das Indústrias do Estado de São Paulo) (2017). Cinco Maiores Bancos da China Apresentam Oportunidades de Financiamento na Fiesp. http://www.fiesp.com.br

Frazao, F. (2016, October 14). Brazil wants to Facilitate Access for Brazilian Companies to India. http://www.brazil.gov.br/

Frias, M., \& Coelho, L. (2018, 23 de Janeiro). Investimento Estrangeiro no Brasil Chega a US\$ 75 bilhoes em 2017. Folha de Sao Paulo. http://www.folhape.com.br

Fung, K., \& Garcia-Herrero, A. (2012). Foreign Direct Outflows from China and India. China Economic Policy Review, 1, Article ID: 1250003.

https://doi.org/10.1142/S1793969012500033

Fung, K., Garcia-Herrero, A., \& Seade, J. (2015). Beyond Minerals: China-Latin America Trans-Pacific Supply Chain. BOFIT Policy Brief, No.5, Bank of Finland.

Furtado, C. (2005). Formacao Economica do Brasil. Companhia Editora Nacional.

Gouvea, R. (2016). The Sinicization of Brazil's Defense Industry. Journal of Defense Studies and Resource Management, 4, 1-25. https://doi.org/10.4172/2324-9315.1000125

Gouvea, R. (2020). Brazil: Chartering a New Economic Pathway. International Business Research, 13, 145-160. https://doi.org/10.5539/ibr.v13n1p145

Gouvea, R., \& Kassicieh, S. (2009). Sowing Strategic Alliances in the Americas: The Sini- 
cization of Latin American Economies. International Journal of Emerging Markets, 4, 315-334. https://doi.org/10.1108/17468800910991223

Guilhon-Albuquerque, J. A. (2017). U.S., China and Brazil: Do We Need Three to Samba? In D. B. H. Denoon (Ed.), China, The United States, and the Future of Latin America (Vol. 3, pp. 162-184). New York University Press.

Harris, R., \& Arias, A. (2016). China's South-South Cooperation with Latin America and the Caribbean. Journal of Developing Societies, 32, 508-556. https://doi.org/10.1177\%2F0169796X16674108

Herrero, A., \& Xu, J. (2019, February 6). Countries's Perceptions of China's Belt and Road Initiative: A Big Data Analysis. Working Paper, Issue 1. http://www.bruegel.org

Hornby, L. et al. (2017, June 3). HNA, o Comprador mais Agressivo da China (p. B.6). Valor.

Ianni, O. (1992). A Ideia de Brasil Moderno. Editora Brasiliense.

Jank, M. (2015, October 17). O Brasil e as Cadeias Globais (pp. A.32). Folha de Sao Paulo.

Kume, O., Piani, G., \& Miranda, P. (2005). India-Mercosul: Perspectivas de um Acordo de Preferencias Comerciais. Discussion Papers No.1120. Instituto de Pesquisas Economicas Aplicadas.

Kuwayama, M. (2012). Brazil and India: Two BRICS as a "Building Bloc" for South-South Cooperation. United Nations Economic Commission for Latin America and the Caribbean.

Lederman, D., Olarreaga, M., \& Perry, G. (2007). Latin America's Response to China and India: Overview of Research Findings and Policy Implications. Revista de Economía y Estadística, 45, 151-193.

Lin, J., \& Wang, Y. (2016). Going Beyond Aid: Development Cooperation for Structural Transformation. Cambridge University Press.

Maia, C., \& Polito, R. (2017a, July 27). Estrangeiras Devem Avancar sobre Espaco das Estatais Eletricas (p. B.1). Valor.

Maia, C., \& Polito, R. (2017b, December 14). Chineses e Indianos Podem Dominar Leilao de Transmissao. http://www.valor.com.br

Mantoan, V., \& Pires, F. (2017, July 14). Odebrecht Passa Galeao para a Chinesa HNA por $60 \mathrm{mi}$ (p. B.2). Valor.

Martins, A. (2015, October 7). Desaquecimento da Economia Chinesa tira 0.3\% ponto do PIB Brasileiro, projeta estudo (p. A.3). Valor.

Maximo, L. (2017, July 20). Investimento da China no Brasil Cresceu 13\% em 2016 (p. A.4). Valor.

Miner, S. (2017, May 23). Why Argentina's Macri Switched Gears on China, now his Favorite Business Partner. http://www.worldpoliticsreview.com

Moreira, A. (2015, October 7). China Avisa que Pode Acionar OMC Contra o Brasil (p. A.3). Valor.

Niu, H. (2016). A New Era of China-Latin America Relations. http://www.cries.org

Oliveira, R. (2018). Indianos no Brasil: Conheca as Marcas que Vendem Utilitarios e Motos no Pais. http://www.noticiasautomotivas.com.br

Olmos, M. (2017, July 25). Sao Paulo quer Apoio do Setor Privado e da China para Destravar Transporte (p. A.2). Valor.

Peters, E. (2015). China's Evolving Role in Latin America. Can It be a Win-Win? Atlantic Council, Adrienne Arsht Latin America Center. 
Peters, E., \& Armony, A. (2017). Effects of China on the Quantity and Quality of Jobs in Latin America and the Caribbean. International Labour Organization.

Powell, D. (2017). China-Brazil Economic Relations: Too Big to Fail? In M. Myers, \& C. Wise (Eds.), The Political Economy of China-Latin America Relations in the New Millennium (Chapter 11, pp. 243-265). Routledge.

Prasad, A., \& Chakraborty, D. (2012). India \& Brazil go Hand-in-Hand on the Road to Progress. Paper Presented at the FICCI Indo-Brazil Summit, 30 March 2012, 1-3.

Ray, R., \& Gallagher, K. (2017). China Latin America Economic Bulletin 2017 Edition. Discussion Paper 2017-1, BU Global Economic Governance Initiative.

Rosa, S. (2017, May 30). Bancos Multilaterais Estrangeiros Ampliam Atuacao no Brasil (p. C.1). Valor.

Santana, M. L., Pereira, R. J., Bignardi, A. B., El Faro, L., Tonhati, H., \& Albuquerque, L. G. (2014). History, Structure, and Genetic Diversity of Brazilian Gir Cattle. Livestock Science, 163, 26-33. https://doi.org/10.1016/j.livsci.2014.02.007

SEAIN (2018). Boletim Bimestral sobre Investimentos Chineses no Brasil-no.2. Ministerio do Planejamento, Desenvolvimento e Gestao.

Seshasayee, H. (2018). India's Rising Presence in Latin America. America's Quarterly. http://www.americasquarterly.org

Simonsen, M. (1974). A Nova Economia Brasileira. Jose Olympio Editora.

Sinate, D., Fanai, V., \& Bangera, S. (2016). Intra-Brics Trade: An Indian Perspective. EXport-Import Bank of India. http://www.eximbankindia.in.

The Dollar Business (2018). India and Brazil have signed the Investment Facilitation Treaty. http://www.thedollarbusiness.com

The Economist Intelligence Unit (2016). The Evolving Role of China in Africa and Latin America.

The Heritage Foundation (2018). The Economic Freedom Index. http://www.heritage.org/

Transparency International (2018). The Corruption Perception Index. http://www.transparency.org/

Trinkunas, H. (2020). Testing the Limits of China and Brazil's Partnership. Brookings, July 20th. http://www.brookings.edu/

United Nations (2018). World Economic Situation and Prospects 2018. United Nations.

Valor (2017, August 5). Brasil Depende da Argentina e China no Superavit Comercial (p. A.10). 5 de Agosto.

Wang, S. (2016). China and Latin America in 2016. Council on Hemispheric Affairs.

Wise, C., \& Myers, M. (2017). The Political Economy of China-Latin America Relations in the 21st Century. In M. Myers, \& C. Wise (Eds.), The Political Economy of China-Latin America Relations in the New Millennium (pp. 1-12). Routledge.

World Bank (2018). Doing Business 2018. The World Bank.

World Economic Forum (2018). The Competitiveness Index. http://www.weforum.org/

Zafalon, \& Mauro (2019, January 10). Apetite da China por Agro Brasileiro vai Alem da Soja e se Diversifica em 10 anos (p. A.20). Folha de Sao Paulo.

Zhao, Y. (2018). The Chinese Policy on Overseas Foreign Direct Investments: Approach and Limits in Brazil. Instituto de Relacoes Internacionais, Universidade de São Paulo. 